\title{
Identification of potential areas for out-scaling sustainable land management options in West Asia, North Africa, and Central Asia
}

\author{
Feras Ziadat $^{\mathrm{a}}$, Mira Haddad ${ }^{\mathrm{b}}$, Theib Oweis ${ }^{\mathrm{b}}$, and Akmal Akramkhanov ${ }^{\mathrm{c}}$ \\ a) Land and Water Division, Food and Agriculture Organization of the United Nations (FAO), Rome, Italy. \\ b) International Center for Agricultural Research in the Dry Areas (ICARDA), Amman, Jordan. \\ c) International Center for Agricultural Research in the Dry Areas (ICARDA), Tashkent, Uzbekistan.
}

\begin{abstract}
Water scarcity and land degradation are among the most important factors affecting agricultural production and sustainability in the West Asia and North Africa (WANA) region and in Central Asia (CA). Various sustainable land management (SLM) technologies that help conserve and better use natural resources and hence improve the incomes and livelihoods of farmers are available and being adapted to these regions. However, to achieve better adoption by farmers and to ensure positive results from implementation, the SLM technologies in WANA and CA need to be disseminated on a large scale. Identifying the potential areas to target the implementation of selected SLM practices is necessary to help decision makers and facilitate the out-scaling process.
\end{abstract}

With participation of specialists from the National Agriculture Research Systems, three agro-ecosystems, rangeland, irrigated, and rainfed, were defined for the WANA region, and the mountain agroecosystem was added for $C A$. Each agro-ecosystem was represented by a benchmark site where selected SLM technology was demonstrated. In WANA, these benchmark sites included the water harvesting Vallerani system (contour ridges and semicircular bunds) for rangeland, water-saving (raised-beds and deficit irrigation) for irrigated, and supplemental irrigation for rainfed agro-ecosystems. In $C A$, sites included pasture improvement for rangeland, raised-beds for irrigated, conservation agriculture for rainfed, and agro-forestry for mountain agro-ecosystems. The criteria used to identify potential areas for out-scaling consisted of land use, slope, water resources availability, precipitation, degree of land degradation, livestock density, soil depth, soil texture, and soil salinity.

Global spatial datasets, such as the FAO Land Degradation Assessment in Drylands project (LADA), soil data from the Harmonized World Soil Database (HWSD), and soil depth from the Soil Map of the World were used to derive the required database. Available national data provided by the participating countries were used as supplemental sources. The derived maps were validated and verified by an interdisciplinary team of experts and researchers from the countries in both regions.

Verification of the maps derived at regional level - using low resolution data, with more detailed data for some countries indicated that potential areas for out-scaling SLM could be generally identified. However, for implementation purposes and to derive the extent of the potential areas, detailed data at national level is needed. Yet, the results are useful to guide decision makers to first identify the extent and distribution of the potential areas for each SLM and agroecosystem and, second, to prioritize the implementation. This will help in the out-scaling of SLM options to improve productivity and resilience.

Keywords: benchmark, agro-ecosystem, spatial analysis, biophysical criteria, knowledge dissemination, decision support mapping

\section{INTRODUCTION}

Evaluation of the spatial pattern of a landscape is necessary to achieve proper land use (FAO, 1996; Roetter et al., 2005; Baja et al., 2007). Recently, geographic information systems (GIS) provide tools and algorithms to determine land uses that are most appropriate for a given area (Collins et al., 2001), and hence provide support for making spatial decisions (Malczewski, 1999). The GIS system contains a set of procedures that facilitate the data input, storage, manipulation and analysis, and data output to support decision-making activities (Grimshaw, 1994). In this project, ArcGIS 10.2 was used for identifying potential areas for out-scaling specific technologies. The selection of potential areas to out-scale any particular use or management is determined by the criteria used to identify these areas, which might vary according to the quantitative and qualitative information available and also its interpretation through the different actors and decision makers (Hurni, 2000). This is related to natural processes and the built environment (Berry and BenDor, 2015). Three approaches could be used to identify areas for out-scaling sustainable land management options: computer-assisted overlay mapping, multi-criteria decision making (MCDM), and artificial intelligence (Chakma, 2014; Malczewski, 2004).

Malczewski (1999) stressed the complexity in attempting to acquire data and to process the data to obtain information for making decisions. This problem may require processing at a level that exceeds a decision maker's cognitive ability. To this end, the role of GIS and multi-criteria decision making (MCDM) techniques support the decision maker in achieving greater 
effectiveness and efficiency of decision making while solving spatial decision problems. GIS-based MCDM can be thought of as a process that combines and transforms aspatial data (input) into a resultant decision (output) (Malczewski, 2004). The MCDM procedures (or decision rules) define a relationship between the input maps and the output map.

The procedures involve the utilization of geographical data, the decision maker's preferences and the manipulation of the data and preferences according to specified decision rules (selected criteria and rating). Accordingly, two considerations are of critical importance for spatial MCDA: (i) the GIS capabilities of data acquisition, storage, retrieval, manipulation and analysis, and (ii) the MCDM capabilities for combining the geographical data and the decision maker's preferences into unidimensional values of alternative decisions.

A number of multi-criteria decision rules have been implemented in the GIS environment for tackling land-use and suitability problems. Furthermore, the combination of GIS capabilities with MCDM techniques provides the decision maker with support in all stages of decision making, that is, in the intelligence, design and choice phases of the decision-making process (Carver, 1991; Pereira et al., 1993; Laaribi et al., 1996; Malczewski, 1996; Malczewski, 1999; Thill, 1999; Chakhar and Martel, 2003; Chakhar and Mousseau, 2006; Malczewski, 2006 ) .

For relatively small areas, a field survey carried out by experienced people will be the best technique to select the appropriate sites and to determine proper sustainable land use and management, for example, rainwater harvesting intervention (Ziadat et al., 2012). For larger areas the application of GIS and remote sensing could be the most relevant means (Prinz et al., 1998; De Pauw et al., 2007; Makhamreh, 2011). However, planning for large scale implementation requires quantitative information and knowledge of the spatial distribution of the land characteristics, which are often unavailable for arid environments (Prinz et al., 1998).

In ICARDA, the integrated water and land management program IWLMP uses GIS in defining potential areas for outscaling specific technologies. The study of "Integrating expert knowledge in GIS to locate biophysical potential for water harvesting - methodology and a case study of Syria" aimed to provide a rapid GIS-based analytical technique to assess suitability for various water harvesting systems in Syria, with the ultimate objective to adapt the technique in order to allow assessment of potential at the level of central and west Asia and North Africa CWANA region (De Pauw et al., 2008).

Identifying potential areas for out-scaling specific SLM techniques within large geographical areas such as WANA and CA - the use MCDM inside a GIS environment and taking into consideration the expert knowledge and assessment - provide profound basis for supporting variable decision makers.

\section{MATERIALS AND METHODS}

\section{A. Identifcation of agro-ecosystems type and charchtaristics}

Different agro-ecosystems have been identified in both WANA and CA regions based on national and international expert's assessments and the knowledge gained from the ICARDA benchmark sites. For these agro-ecosystems specific SLM technologies have been chosen according to defined criteria, the criteria evaluated during several regional workshops and meetings. The water benchmark project for WANA region "Community-Based Optimization of the Management of Scarce Water Resources in Agriculture in West Asia and North Africa" started in 2004 with the aim to increase adoption of improved technologies, and thus to improve water productivity and livelihoods in water scarce environments. The project targeted three agro-ecosystems: marginal rangelands (steppe), rainfed cropping systems, and irrigated areas. In each agro-ecosystem, a pilot research site was established to test and demonstrate new technologies. Moreover, two or more 'satellite' sites were established (for each pitot site) for complementarity and for wider dissemination. Research focused on the key water-related issues (or opportunity) in each environment; in the Rainfed agroecosystem (Tadla region in Morocco) with satellite sites in Tunisia and Algeria, the Irrigated agro-ecosystem (Old, Marginal and New lands in Egypt) with Satellite sites in Sudan and Iraq and the Badia agro-ecosystem (Al Majdyya and Al Maharib in Jordan) with satellite sites in Syria and Libya. (Fig. 1). The characteristics of the benchmark sites (research sites) where successful technologies were tested, were used to identify areas similar to articular agro-ecosystem (Table I). The requirements for each technology that ensure successful implementation and out-scaling were used to identify potential areas for out-scaling each technology (Tables II and III). These criteria were matched with land resources data to map the distribution of the agroecosystems and the areas for potential out-scaling of SLM.

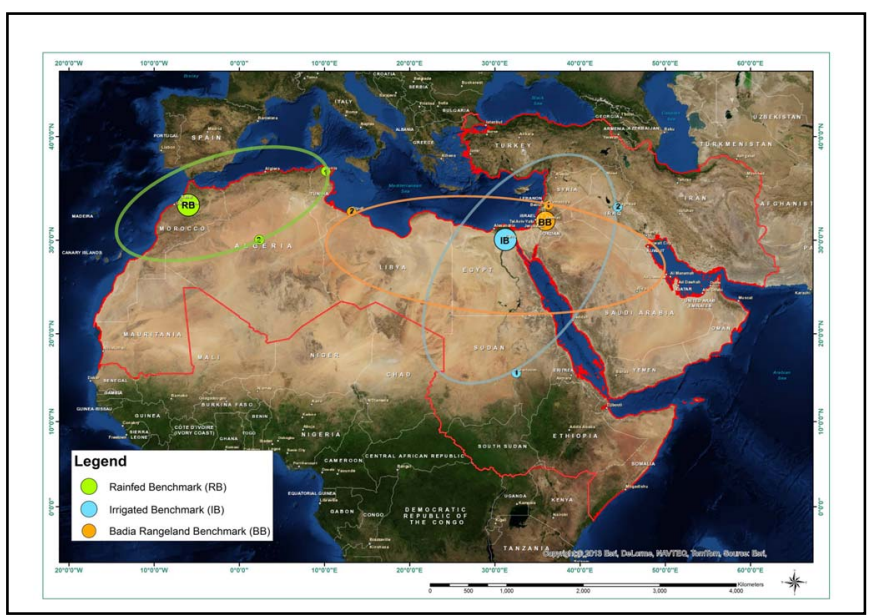

Fig. 1. Locations of the agro-ecosystem sites and satellite sites in West Asia and North Africa region 


\section{B. Data sources}

To conduct comprehensive analysis for identifying the potential areas for out-scaling, different spatial datasets are needed. For large scale applications - as it is the case for the particular operations in WANA and CA region - the use of data from online sources seems feasible. The different datasets available were explored carefully, compared to each other, and discussed with different scientists and experts in order to have representative layers. The data were selected due to their relevance and appropriateness for the SLM analyses (Table IV).

TABLE I. IMPORTANT CHARACTERISTICS OF AGRO-ECOSYSTEMS SITES IN WEST ASIA AND NORTH AFRICA REGION

\begin{tabular}{|c|c|c|}
\hline $\begin{array}{c}\text { Agro- } \\
\text { ecosystem }\end{array}$ & Criteria & Detailed \\
\hline \multirow{3}{*}{$\begin{array}{l}\text { Rainfed in } \\
\text { Morocco }\end{array}$} & Rainfall (mm) & $250-600$ \\
\hline & $\begin{array}{l}\text { Land is } \\
\text { cultivated }\end{array}$ & Crop lands \\
\hline & Slope (\%) & up to 25 \\
\hline \multirow{4}{*}{$\begin{array}{c}\text { Irrigated in the } \\
\text { Nile Delta, } \\
\text { Egypt }\end{array}$} & Water resources & Permanent water resources \\
\hline & $\begin{array}{l}\text { Land is } \\
\text { cultivated }\end{array}$ & Crop land \\
\hline & Soil texture & All soil texture classes \\
\hline & Slope $(\%)$ & $<5$ \\
\hline \multirow{4}{*}{$\begin{array}{c}\text { Rangeland in } \\
\text { the Jordan } \\
\text { Badia }\end{array}$} & Rainfall (mm) & $50-300$ \\
\hline & $\begin{array}{ll}\text { Land } & \text { is } \\
\text { cultivated } & \end{array}$ & $<50 \%$ vegetation cover \\
\hline & Slope (\%) & $0-50$ \\
\hline & Soil texture & All soil texture classes \\
\hline
\end{tabular}

TABLE II. CRITERIA USED TO IDENTIFY POTENTIAL AREAS FOR OUTSCALING SPECIFIC TECHNOLOGIES WITHIN THE THREE AGRO-ECOSYSTEMS IN WEST ASIA AND NORTH AFRICA REGION

\begin{tabular}{|c|c|c|}
\hline $\begin{array}{l}\text { Technology/A } \\
\text { gro-ecosystem }\end{array}$ & Criteria & Detailed \\
\hline \multirow{5}{*}{$\begin{array}{c}\text { Supplemental } \\
\text { irrigation/ } \\
\text { Rainfed }\end{array}$} & Rainfall (mm) & $250-500$ \\
\hline & Water resources & $\begin{array}{l}\text { Available for supplemental } \\
\text { irrigation }\end{array}$ \\
\hline & $\begin{array}{l}\text { Land is } \\
\text { cultivated }\end{array}$ & Crop lands \\
\hline & Crops & Winter crops based system \\
\hline & Slope $(\%)$ & up to 5 \\
\hline \multirow{4}{*}{$\begin{array}{l}\text { Raised-bed } \\
\text { technologies/ } \\
\text { Irrigated }\end{array}$} & Rainfall (mm) & $<250$ \\
\hline & Water resources & $\begin{array}{l}\text { available for supplemental } \\
\text { irrigation }\end{array}$ \\
\hline & Land use & Land that is cultivated \\
\hline & Soil texture & Not Sandy \\
\hline \multirow{5}{*}{$\begin{array}{c}\text { Vallerani water } \\
\text { harvesting/ } \\
\text { Rangeland }\end{array}$} & Rainfall (mm) & $100-300$ \\
\hline & Soil depth $(\mathrm{cm})$ & $60 \mathrm{~cm}$ and more \\
\hline & Land use & $<30 \%$ vegetation cover \\
\hline & Slope (\%) & up to 20 \\
\hline & Soil texture & Not Sandy \\
\hline
\end{tabular}

TABLE III. CRITERIA USED TO IDENTIFY POTENTIAL AREAS FOR OUTSCALING SPECIFIC TECHNOLOGIES WITHIN THE FOUR AGRO-ECOSYSTEMS in CENTRAL ASIA REGION

\begin{tabular}{|c|c|c|}
\hline $\begin{array}{l}\text { Technology/A } \\
\text { gro-ecosystem }\end{array}$ & Criteria & Detailed \\
\hline \multirow{4}{*}{$\begin{array}{c}\text { Fig. 1. Conse } \\
\text { rvation } \\
\text { agricultu } \\
\text { re/ } \\
\text { Rainfed }\end{array}$} & $\begin{array}{l}\text { Fig. 2. Rainfall } \\
(\mathrm{mm})\end{array}$ & Fig. 3. $300-600$ \\
\hline & Slope (degree) & $<7$ \\
\hline & Land use & Cropland \\
\hline & $\begin{array}{l}\text { Soil (texture), clay } \\
\text { content }(\%)\end{array}$ & $20-75$ physical clay \\
\hline \multirow{5}{*}{$\begin{array}{l}\text { Raised-bed } \\
\text { technologies / } \\
\text { Irrigated }\end{array}$} & Land use & Irrigated land \\
\hline & Slope (degree) & $0-5$ \\
\hline & Water availability & Sufficient water resources \\
\hline & $\begin{array}{l}\text { Soil (texture), clay } \\
\text { content }(\%)\end{array}$ & $10-75$ \\
\hline & $\begin{array}{l}\text { Soil salinity (dS } \\
\mathrm{m}-1)\end{array}$ & $<8$ \\
\hline \multirow{5}{*}{$\begin{array}{l}\text { Mountain } \\
\text { agro-forestry/ } \\
\text { Mountain }\end{array}$} & Slope (degree) & $>7$ \\
\hline & Rainfall (mm) & $>500$ \\
\hline & Altitude (m) & $800-3000$ \\
\hline & Land use & $\begin{array}{l}\text { Exclude unsuitable areas (e.g. } \\
\text { rocks and gullies) }\end{array}$ \\
\hline & Soil depth $(\mathrm{cm})$ & $>50$ \\
\hline \multirow{4}{*}{$\begin{array}{l}\text { Pasture } \\
\text { improvement/R } \\
\text { angeland }\end{array}$} & Land use & Rangeland, pasture \\
\hline & $\begin{array}{l}\text { Degradation } \\
\text { degree }\end{array}$ & $\begin{array}{l}\text { Areas with weak, medium to } \\
\text { strong degradation, and } \\
\text { bareland }\end{array}$ \\
\hline & $\begin{array}{l}\text { Livestock density } \\
\text { per ha }\end{array}$ & $\begin{array}{l}\text { Areas with high and moderate } \\
\text { livestock density }\end{array}$ \\
\hline & $\begin{array}{l}\text { Watering points } \\
\text { per ha }\end{array}$ & Existence of watering points \\
\hline
\end{tabular}

\section{Data preparation}

Available data from different sources vary in resolution and format. Thus, data harmonization has been undertaken to ensure uniformity of the data and to run the analysis for defined resolution and quality.

Resampling, raster calculation, and conditional functions were among the GIS spatial analysis tools used to extract the needed data layers. As an example - to extract the land use needed for the potential areas for raised-bed technology within areas suitable for irrigated agro-ecosystem, the following code was used for the GIS raster calculator (IF-statement):

$$
\begin{gathered}
\text { Con (("lu_t1_500m"==12) | ("lu_t1_500m" } \\
\left.==14), " l u \_t 1 \_500 \mathrm{~m} "\right)=\mathrm{LU}
\end{gathered}
$$

\section{Mapping production}

After processing each data set, raster calculator function was used to produce a uniform layer that includes all the criteria representing the spatial distribution of each agro-ecosystem. For example, to produce the potential areas for Vallerani water 
harvesting technique within the rangeland agro-ecosystem areas, the following code was used (AND-statement) :

$$
\text { "Rainfall" \& "Soil_Depth" \& "LU” \& "Slope" \& }
$$

TABLE IV. DATA USED FOR IDENTIFYING THE POTENTIAL AREAS FOR

\begin{tabular}{|c|c|}
\hline Criteria & Detailed \\
\hline Rainfall & $\begin{array}{l}\text { WorldClim - Global Climate Data } \\
\text { http://www.worldclim.org/download } \\
\text { Global Weather Data for SWAT } \\
\text { Http://globalweather.tamu.edu/ }\end{array}$ \\
\hline Land use & $\begin{array}{l}\text { Land Processes -Distributed Active Archive Center LP } \\
\text { DAAC, United States Geological Survey USGS } \\
\text { Https://pdaac.usgs.gov/products/MODIS } \\
\text { products_table/mcd12q1 } \\
\text { Food and Agriculture Organization of the United Nation } \\
\text { FAO, The Land Degradation Assessment in Drylands } \\
\text { project LADA, Global Land Degradation Information } \\
\text { System GLADIS - Simplified output, Land use systems } \\
\text { of the world - v1.1 } \\
\text { http://www.fao.org/nr/lada/gladis/lus/ } \\
\text { FAO, Effective Soil Depth (cm) Map, Class 10 } \\
\text { http://data.fao.org/map?entryId=c3bfc940-bdc3-11db- } \\
\text { a0f6-000d939bc5d8 } \\
\text { FAO- GeoNetwork, Digital Soil Map of the World } \\
\text { http://www.fao.org/geonetwork/srv/en/metadata.show?id } \\
=14116\end{array}$ \\
\hline Soil & $\begin{array}{l}\text { FAO, Effective soil depth }(\mathrm{cm}) \text { map } \\
\text { http://data.fao.org/map?entryId=c3bfc940-bdc3-11db- } \\
\text { a0f6-000d939bc5d8 } \\
\text { WaterBase project } \\
\text { Http://www.waterbase.org/download_data.html } \\
\text { FAO, GeoNetwork, digital Soil Map of the World } \\
\text { http://www.fao.org/geonetwork/srv/en/metadata.show?id } \\
=14116 \\
\text { Harmonized world soil database HWSD -Version } 1.2 \\
\text { http://webarchive.iiasa.ac.at/Research/LUC/External- } \\
\text { World-soil-database/HTML/ }\end{array}$ \\
\hline Water & $\begin{array}{l}\text { World Wildlife Fund WWF, Conservation Science Data } \\
\text { and Tools, Global Lakes and Wetlands Database GLWD } \\
\text { http://worldwildlife.org/pages/global-lakes-and- } \\
\text { wetlands-database } \\
\text { FAO - AQUASTAT - global water information system } \\
\text { Http://www.fao.org/nr/water/aquastat/main/index.stm } \\
\text { Environmental Systems Research Institute ESRI; World } \\
\text { Water Bodies and World Linear Water } \\
\text { http://www.arcgis.com/home/item.html?id=e750071279 } \\
\text { bf450cbd510454a80f2e63; and } \\
\text { http://www.arcgis.com/home/item.html?id=273980c20b } \\
\text { c74f94ac96c7892ec15aff }\end{array}$ \\
\hline DEM & $\begin{array}{l}\text { The Consultative Group for International Agricultural } \\
\text { Research - Consortium for Spatial Information CGIAR } \\
\text { CSI - Shuttle Radar Topography Mission SRTM } 90 \mathrm{~m} \\
\text { digital elevation data } \\
\text { http://srtm.csi.cgiar.org/ (this data used to extract the } \\
\text { altitude (m) and the slope (degree) }\end{array}$ \\
\hline
\end{tabular}
OUT-SCALING SPECIFIC SLM TECHNOLOGIES IN WANA AND CA REGIONS

\begin{tabular}{|c|l|}
\hline $\begin{array}{c}\text { Degradation } \\
\text { degree }\end{array}$ & $\begin{array}{l}\text { FAO, LADA, GLADIS - Simplified output, Classes of } \\
\text { land degradation } \\
\text { http://www.fao.org/nr/lada/gladis/glad_ind/ }\end{array}$ \\
\hline $\begin{array}{c}\text { Livestock } \\
\text { density per } \\
\text { ha }\end{array}$ & $\begin{array}{l}\text { FAO, LADA, GLADIS - Simplified output, Classes of } \\
\text { land degradation } \\
\text { Beta version, Livestock density } \\
\text { http://www.fao.org/nr/lada/gladis/lus/ }\end{array}$ \\
\hline
\end{tabular}

\section{RESULTS}

Two results for WANA region are available, one for the distribution of the three agro-ecosystems (similar to the three research sites) and the other for the distribution of potential areas for out-scaling specific technologies within the three agroecosystems. The resulting maps indicate clustered areas that represent similar characteristics as the areas where specific agroecosystems are distributed.

Thus, maps (Figures 2-4) show significant areas where specific technologies may be out-scaled. This varies from country to country and could be used to build specific information dissemination and out-scaling campaigns for each one. The analysis for the selected SLM shows areas less than those suitable to the agro-ecosystem because these are more specific (Table V). They show areas where selected SLM technologies can be applied within the whole area. However, other SLM practices could be implemented within the areas similar to those of the agro-ecosystem sites.

To verify the results for the WANA region, additional data from national agriculture research systems NARS in Jordan, Morocco, and Egypt were used to run the same analysis but using more detailed data. Professional version of Google Earth and the Global Land Cover data base (2009) from the European Space Agency were used to support the verification process. In general, an acceptable agreement between the two methodologies was found - even though the data used for entire WANA region analysis has much lower resolution compared to the datasets used at the national level. In CA the analysis of identifying potential areas for out-scaling the selected technologies shows highly variable distributions of the four agro-ecosystems according to the different countries (Fig. 5).

Most of CA countries, Uzbekistan, Kazakhstan, Kyrgyzstan, and Tajikistan provided data about the area of rainfed and irrigated land to support the analysis at regional level (Table VI). The national data was checked for consistency and was used as input to revise and fine-tune the mapping (Fig. 6).

To verify the results, the experience and knowledge of national experts and representatives from NARS was taken into consideration during a regional workshop, using the professional version of Google Earth for presenting and discussing the results. 


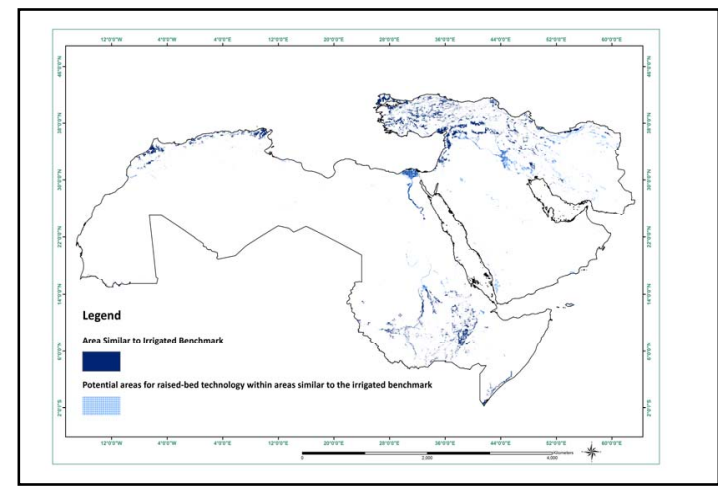

Fig. 2. Distribution of areas similar to the irrigated agro-ecosystem and potential areas for out-scaling raised-bed technology

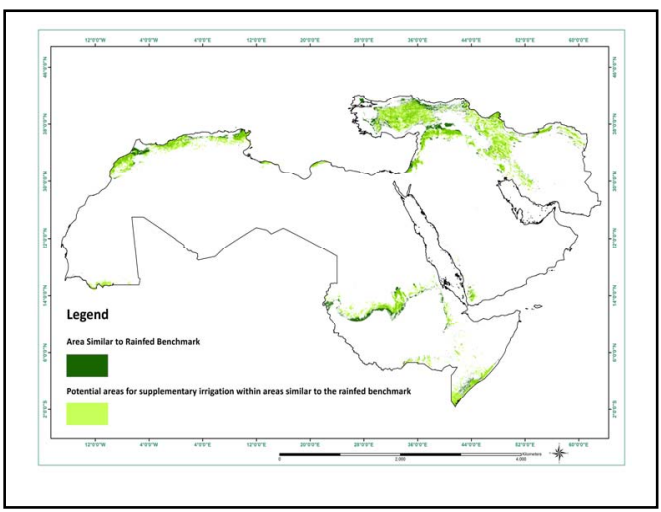

Fig. 3. Distribution of areas similar to the rainfed agro-ecosystem and potential areas for out-scaling supplementary irrigation

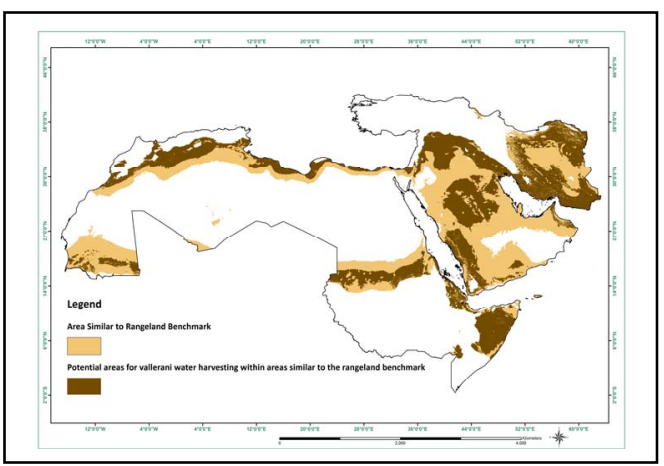

Fig. 4. Distributioon of areas similar to the rangeland agro-ecosystem and potential areas for out-scaling Vallerani water harvesting

TABle V. Potential AREas For Out-Scaling Selected TeChNOlogies IN WeSt ASIa AND NORTh AFRICA REgION

\begin{tabular}{|l|l|}
\hline \multicolumn{1}{|c|}{ Description } & \multicolumn{1}{|c|}{ Area (km2) } \\
\hline $\begin{array}{l}\text { Rainfed Agro-ecosystem } \\
\text { Area for out-scaling supplementary irrigation } \\
\text { within the rainfed agro-ecosystem }\end{array}$ & $349,046.7$ \\
\hline $\begin{array}{l}\text { Irrigated Agro-ecosystem } \\
\text { Area for out-scaling raised-bed technology within } \\
\text { the irrigated agro-ecosystem }\end{array}$ & 2497.9 \\
\hline Rangeland Agro-ecosystem & $754,11.2$ \\
\hline
\end{tabular}

\begin{tabular}{l|l} 
Area for out-scaling Vallerani water harvesting & $3,240,797.2$
\end{tabular} within the rangeland agro-ecosystem

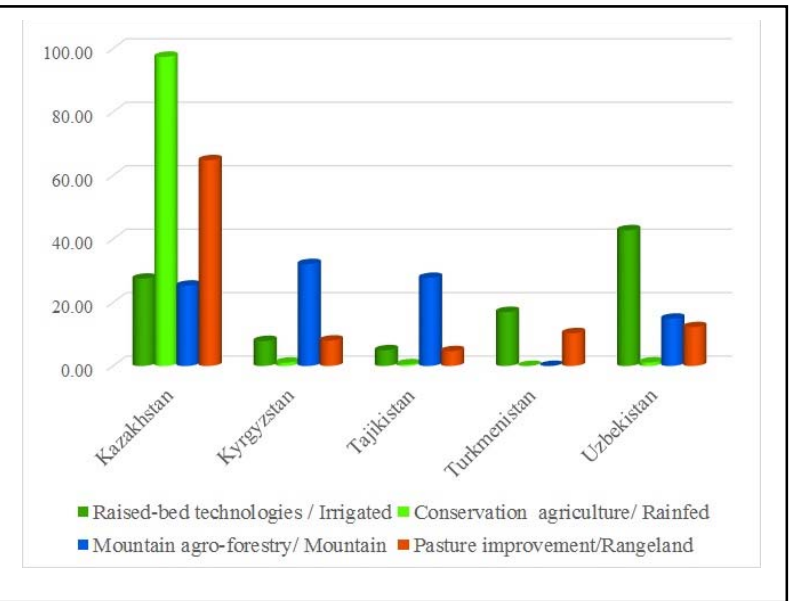

Fig. 5. Potential areas for out-scaling selected technologies in CA region (as perecent of the area of the counties)

TABLE VI. NATIONAL DATA USED FOR FINE-TUNING THE THE SLM ANALYSIS MAPS IN CA REGION

\begin{tabular}{|c|l|}
\hline Country & \multicolumn{1}{|c|}{ Data sources } \\
\hline Uzbekistan & $\begin{array}{l}\text { Soil map of the Republic of Uzbekistan, produced by } \\
\text { GOSCOMZEMGEODESCADASTRE in 2008 } \\
\text { Atlas of Soil Cover of the Republic of Uzbekistan, } \\
\text { printed by GOSCOMZEMGEODESCADASTRE in } \\
2010\end{array}$ \\
\hline Kazakhstan & $\begin{array}{l}\text { Socio-economic atlas of Republic of Kazakhstan, Vol. 2, } \\
\text { Land use map, produced by Institute of Geography in } \\
2010\end{array}$ \\
\hline Kyrgyzstan & $\begin{array}{l}\text { Land use map of Kyrgyz Republic. The report Ms. } \\
\text { Kelgenbaeva Kamila. The results of IP-SLM, CACILM } \\
\text { Phase I (Information system component, 2008-2010) }\end{array}$ \\
\hline Tajikistan & $\begin{array}{l}\text { Atlas of the Tajik SSR, Soil and Land use Map, } \\
\text { produced by the Department of Geodesy and } \\
\text { Cartography under the Council of Ministers of the USSR } \\
\text { in 1968 }\end{array}$ \\
\hline
\end{tabular}

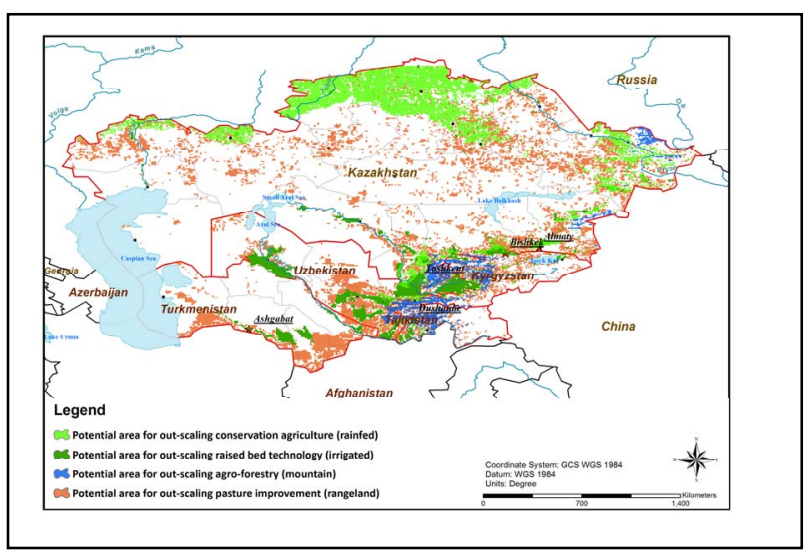

Fig. 6. Potential areas for out-scaling different sustainable land management technologies within four agro-ecosystems in Central Asia (irrigated, rainfed, rangeland, and mountain) 


\section{CONCLUSION}

The study discloses the potential to identify areas for outscaling SLM options based on the available coarse resolution data for WANA and CA. These maps could be used to support the allocation of areas within different agro-ecosystems for dissemination and promotion of proper water and land management options. Identification of proper criteria for characterizing each agro-ecosystem is important for generating reliable results. . A comparison of the outcomes based on the online available data sources with those derived for the national level using similar criteria supported our fine-tuning process. The resulting maps cover the whole area of interest with acceptable accuracy. Eventually, those maps can be used to guide decision makers at regional and national levels. The participation of national experts in formulating the criteria for verifying and finetuning of these maps was important and will supports the dissemination of the results and foster implementation by decision makers. At regional level, donors and/or development programs could benefit from these results by identifying areas to put more efforts into out-scaling of technologies that will lead to higher impact. Investments could be directed based on these results to maximize the benefits and success of adopting different technologies. At the local level, farmers, land users, and extension services could use these results to identify potential intervention(s) that will optimize productivity and improve livelihood. This will also help farmers and extension services to suggest new technologies to areas with similar environmental conditions to those where these technologies were tested. Eventually, this will help in adopting these technologies for a wider range and better uptake.

\section{ACKNOWLEDGMENT}

For the WANA analysis, the authors would like to acknowledge the National Center for Agricultural Research and Extension NCARE, Jordan, the National Institute of Agronomic Research of Morocco INRA, and the Agricultural Research Center ARC Egypt for their technical support. For CA analysis, the authors would like to acknowledge the Research Institute of Soil Science and Agrochemistry, Kazakhstan, the Ministry of Agriculture and Melioration, Kyrgyzstan, the Academy of Agricultural Sciences, Tajikistan, and the Research Institute of Soil Science and Agrochemistry, Uzbekistan for their valuable contributions.

\section{REFERENCES}

[1] Baja, S., Chapman, D.M., Dragovich, D., 2007. Spatial based compromise programming for multiple criteria decision making in land-use planning. Environ. Model. Assess. 12 (3), 171-184.

[2] Berry, Marisa and Todd BenDor. 2015. Integrating Sea Level Rise into Development Suitability Analysis. Computers, Environment, and Urban Systems 51: 13-24.

[3] Carver, S.J., 1991. Integrating multi-criteria evaluation with geographical information systems. International Journal of Geographical Information Systems 5 (3), 321-339.
[4] Chakhar S., Mousseau, V. 2006. DMA: An algebra for multicriteria spatial modeling. In: Proccedings ICA Workshop on Geospatial Analysis and Modeling, 8 July, pp. 155-185, Vienna, Austria.

[5] Chakhar, S., Martel, J.M. 2003. Enhancing geographical information systems capabilities with multi-criteria evaluation functions. J. Geogr. Inf. Dec. Anal. 7(2), 47-71.

[6] Chakma, S. 2014. Analysis of urban development suitability. In A. Dewan \& R. Corner (Eds.), Dhaka megacity: Geospatial perspectives on urbanization, environment, and health series (pp. 147-161). Dordrecht: Springer Science.

[7] Collins, Michael G.; Steiner, Frederick R.; Rushman, Michael J. 2001. Land-Use Suitability Analysis in the United States: Historical Development and Promising Technological Achievements. Environmental Management. Vol. 28 Issue 5, p611-21.

[8] De Pauw, E., T. Oweis, and J. Youssef. 2007. Assessment of potential water harvesting by integrating expert knowledge in GIS methodology and a case study in Syria. (ICARDA), Aleppo, Syria. P. 41.

[9] E. De Pauw, T. Oweis, and J. Youssef. 2008. Integrating Expert Knowledge in GIS to Locate Biophysical Potential for Water Harvesting: Methodology and a Case Study for Syria. ICARDA, Aleppo, Syria. iv + 59 pp.

[10] FAO,1996. Guidelines for land-use planning. Food and Agriculture Organization of the United Nations, Rome, Italy.

[11] Feras Ziadat, Adriana Bruggeman, Theib Oweis, Nasri Haddad, Safa Mazahreh, Wael Sartawi \& Maha Syuof (2012): A Participatory GIS Approach for Assessing Land Suitability for Rainwater Harvesting in an Arid Rangeland Environment, Arid Land Research and Management, 26:4, 297-311.

[12] Grimshaw DJ. 1994. Bringing Geographical Information Systems in to Business. Harlow, Essex, England: Longman Scientific and Technical.

[13] Laaribi, A., Chevallier, J.-J., and Martel, J.-M. (1996) A Spatial decision aid: A multicriterion evaluation approach, Computers and Urban Systems, 20(6) 351-366.

[14] Hans Hurni. 2000. Assessing sustainable land management (SLM). Agriculture, Ecosystems and Environment 81 (2000) 83-92.

[15] Makhamreh, Z. 2011. Using remote sensing approach and surface landscape conditions for optimization of watershed management in Mediterranean regions. Physics and Chemistry of the Earth, Parts $A=B=C$ 36(5-6): 213-220.

[16] Malczewski, J., 1996. A GIS-based approach to multiple criteria group decision making. International Journal of Geographical Information Systems 10 (8), 955-971.

[17] Malczewski, J., 1999. GIS and Multicriteria Decision Analysis, Wiley, New York.

[18] Malczewski, J. 2004. GIS-based land-use suitability analysis: A critical overview. Progress in Planning, 62(1), 3-65

[19] Malczewski, J. 2006. Ordered weighted averaging with fuzzy quantifiers: based multicriteria evaluation for land-use suitability analysis. InternationalJournal of Applied Earth Observation and Geoinformation, 8(4), 270-277.

[20] Pereira, J.M.C., Duckstein, L., 1993. A multiple criteria decision-making approach to GIS-based land suitability evaluation. International Journal of Geographical Information Systems 7 (5), 407-424.

[21] Prinz, D., T. Oweis, and A. Oberle. 1998. Rainwater harvesting for dry land agriculture developing a methodology based on remote sensing and GIS, in Proceedings of the XIII. International Congress Agricultural Engineering, 2-6 February, ANAFID, Rabat, Morocco.

[22] Roetter, R.P., Hoanh, C.T., Laborte, A.G., Van Keulen, H., Van Ittersum, M.K., Dreiser, C., Van Diepen, C.A., De Ridder, N., Van Laar, H.H., 2005. Integration of systems network (SysNet) tools for regional land use scenario analysis in Asia. Environ. Model. Software 20 (3), 291-307.

[23] Thill, J.-C.. 1999. Multicriteria Decision-making and Analysis: A Geographic Information Sciences Approach, Ashgate, New York. 